\title{
OPEN Design, synthesis and biological activities of echinopsine derivatives containing acylhydrazone moiety
}

\author{
Peipei Cui ${ }^{1}$, Mingjiang Cai ${ }^{2}$, Yanan Meng ${ }^{2}$, Yan Yang ${ }^{2 凶}$, Hongjian Song ${ }^{3}$, Yuxiu Liu ${ }^{3} \&$ \\ Qingmin Wang $\mathbb{1}^{3 凶}$
}

Based on the broad-spectrum biological activities of echinopsine and acylhydrazones, a series of echinopsine derivatives containing acylhydrazone moieties have been designed, synthesized and their biological activities were evaluated for the first time. The bioassay results indicated that most of the compounds showed moderate to good antiviral activities against tobacco mosaic virus (TMV), among which echinopsine (I) (inactivation activity, 49.5 $\pm 4.4 \%$; curative activity, $46.1 \pm 1.5 \%$; protection activity, $42.6 \pm 2.3 \%$ ) and its derivatives 1 (inactivation activity, $44.9 \pm 4.6 \%$; curative activity, $39.8 \pm 2.6 \%$; protection activity, $47.3 \pm 4.3 \%$ ), 3 (inactivation activity, $47.9 \pm 0.9 \%$; curative activity, $43.7 \pm 3.1 \%$; protection activity, $44.6 \pm 3.3 \%$ ), 7 (inactivation activity, $46.2 \pm 1.6 \%$; curative activity, $45.0 \pm 3.7 \%$; protection activity, $41.7 \pm 0.9 \%$ ) showed higher anti-TMV activity in vivo at $500 \mathrm{mg} / \mathrm{L}$ than commercial ribavirin (inactivation activity, $38.9 \pm 1.4 \%$; curative activity, $39.2 \pm 1.8 \%$; protection activity, $36.4 \pm 3.4 \%)$. Some compounds exhibited insecticidal activities against Plutella xylostella, Mythimna separate and Spodoptera frugiperda. Especially, compounds 7 and 27 displayed excellent insecticidal activities against Plutella xylostell (mortality $67 \pm 6 \%$ and $53 \pm 6 \%$ ) even at $0.1 \mathrm{mg} / \mathrm{L}$. Additionally, most echinopsine derivatives exhibited high fungicidal activities against Physalospora piricola and Sclerotinia sclerotiorum.

Plant virus diseases can be caused by more than 900 viruses, which reduce grain production and lead to huge economic losses all over the world ${ }^{1-3}$. As a well-studied plant virus, tobacco mosaic virus (TMV) belongs to single-stranded RNA virus of the family togaviridae 4 and it can infect 268 species of plants in 38 families, such as tobacco, tomato, pepper, cucumber, causing their leaves to grow spots, wither and even leading to yield reduction ${ }^{5-7}$. Although commercially available plant virus inhibitors ningnanmycin and ribavirin are widely used to control TMV, their inhibitory effects are lower than $60 \%{ }^{8}$. Thus, the development of efficient alternative TMV inhibitors is still in great request.

Natural products are an important source of plant virus inhibitor discovery. Compared with traditional synthetic plant virus inhibitor, plant virus inhibitor derived from natural products have many advantages, including low toxic, environmentally friendly, easy to decompose and specific to target species, $e t c^{9,10}$. Song et al. reported that the $\mathrm{EC}_{50}$ value of purine nucleoside derivative for the inactivating activity against TMV was $48 \mathrm{mg} / \mathrm{L}$, which was better than that of ningnanmycin $(88 \mathrm{mg} / \mathrm{L})^{11}$. Li et al. first found that phenanthroindolizidine alkaloid, (R)-antofine, exhibited a good inhibitory effect against TMV ${ }^{12}$. Wang et al. found some $\beta$-carboline analogues ${ }^{7}$, hemigossypol $^{13}$, dehydrobufotenine derivatives ${ }^{14}$, pityriacitrin marine alkaloids ${ }^{15}$, pulmonarin alkaloids ${ }^{16}$ and hamacanthin derivatives ${ }^{17}$ exhibited higher anti-TMV activities than ningnanmycin. Many other natural alkaloids derivatives were also developed as potential TMV inhibitors ${ }^{18-27}$. Although a variety of natural product derivatives have been found to exhibit high anti-TMV activity, few of them have been applied successfully in agriculture. Thus, it is necessary to discover novel natural TMV inhibitors with diverse structures.

Echinopsine is a quinoline alkaloid isolated from Echinops sphaerocephalus L., the root of which was used as traditional Chinese medicine for treatment of deep-rooted breast carbuncles, ulcer, sodoku and breast milk stoppage. Although the bioactivity of Echinops sphaerocephalus L. extract has been widely studied ${ }^{28}$, the biological activity of echinopsine is still not clear. The anti-TMV activity of echinopsine has not been reported so far. However, a variety of natural alkaloids containing echinopsine moiety showed herbicidal, insecticidal, bactericidal,

${ }^{1}$ College of Arts, Taiyuan University of Technology, Taiyuan 030024, People's Republic of China. ${ }^{2}$ College of Biomedical Engineering, Taiyuan University of Technology, Taiyuan 030024, People's Republic of China. ${ }^{3}$ State Key Laboratory of Elemento-Organic Chemistry, College of Chemistry, Frontiers Science Center for New Organic Matter, Collaborative Innovation Center of Chemical Science and Engineering (Tianjin), Nankai University, Tianjin 300071, People's Republic of China. ${ }^{\circledR}$ email: yy529222@163.com; wangqm@nankai.edu.cn 
<smiles>[R]c1cc(=O)c2ccccc2n1C</smiles>

$\mathrm{R}=\mathrm{C}_{9} \mathrm{H}_{19}$

$\mathrm{R}=\mathrm{C}_{6} \mathrm{H}_{5}$

Trypanocidal activity<smiles>CCCc1c(OC)c(=O)c2ccccc2n1C</smiles>

Leiokinine A Antifeedant activity<smiles>Cn1c2ccccc2c(=O)c2ccoc21</smiles>

Isodictamnine Anti-tumor activity

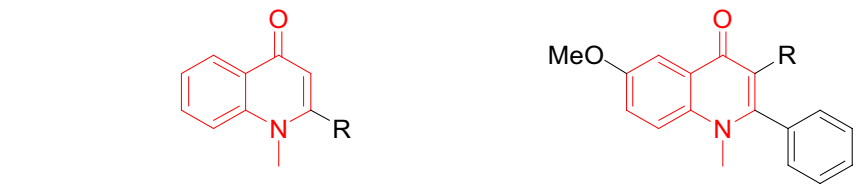

Evocarpine, $\mathrm{R}=(8 \mathrm{Z})-\left(\mathrm{CH}_{2}\right)_{7} \mathrm{CH}=\mathrm{CH}\left(\mathrm{CH}_{2}\right)_{3} \mathrm{Me}$ Dihydroevocarpine $\mathrm{R}=\left(\mathrm{CH}_{2}\right)_{12} \mathrm{Me}$ Insecticidal activity Anti-bacterial activity Immunomodulatory activity Hypolipidaemic activity<smiles>CCC(CC)c1cc(=O)c2ccccc2n1C</smiles>

Leiokinine B Antifeedant activity<smiles>COc1cccc2c(=O)c3ccoc3n(C)c12</smiles>

Iso-y-fagarine Anti-tumor activity

Eduline $\mathrm{R}=\mathrm{H}$ Japonine $\mathrm{R}=\mathrm{OMe}$ Effect on muscle<smiles>Cn1c(-c2ccc3c(c2)OCO3)cc(=O)c2ccccc21</smiles>

Graveoline Anti-tumor activity Herbicidal activity<smiles>COc1ccc2c(=O)c3ccoc3n(CCC(C)(C)O)c2c1</smiles>

Acrophyllidine Cardiovascular protective activity<smiles>C/C(=C\Cc1c(C)c(=O)c2ccccc2n1C)CCC1OC1(C)C</smiles>

CJ-13564 Anti-bacterial activity<smiles>CCCCCc1cc(=O)c2ccccc2n1C</smiles>

Anti-fungal activity<smiles>[R]C1([C@@H](C)CC)NC(=O)c2c1n(C)c1ccccc1c2=O</smiles>

Quinolactacin $\mathrm{R}=\mathrm{\alpha}-\mathrm{H}$ Anti-inflammatory activity Anticholinesterase activity
Figure 1. Natural products and drugs containing the core structure of echinopsine.

anti-tumor, antifungal and antifeedant activities, etc. (Fig. 1) ${ }^{29}$, indicating echinopsine moiety has potential broad-spectrum biological activities. Based on this, the anti-TMV activity of echinopsine was investigated by our group and the result shows that the inactivation, curative and protection activities of echinopsine $(49.5 \pm 4.4 \%$, $46.1 \pm 1.5 \%$ and $42.6 \pm 2.3 \%$ at $500 \mathrm{mg} / \mathrm{L}$, in Table 1$)$ were higher than that of ribavirin $(38.9 \pm 1.4 \%, 39.2 \pm 1.8 \%$, $36.4 \pm 3.4 \%$, at $500 \mathrm{mg} / \mathrm{L}$ ). The biological activities of acylhydrazone compounds have always been the focus of pharmacological research ${ }^{30-33}$. Variety of compounds with acylhydrazone functional group $(-\mathrm{CONHN}=)$ showed good bactericidal, herbicidal or insecticidal activities, such as benquinox ${ }^{34}$, saijunmao ${ }^{35}$, metaflumizone ${ }^{36}$ and diflufenzopyr ${ }^{37}$. Based on the high biological activities of echinopsine and acylhydrazone structure, in order to find echinopsine derivatives with higher anti-TMV activities and summarize their structure-activity relationship, a series of echinopsine derivatives containing acylhydrazone moieties were designed, synthesized and characterized in this work (Fig. 2). Their anti-TMV activities were studied for the first time. Besides, in order to see if these compounds have broad spectrum bioactivity, their insecticidal and fungicidal activities were also investigated.

\section{Materials and methods}

Instruments. ${ }^{1} \mathrm{H}$ NMR spectra were obtained at $400 \mathrm{MHz}$ using a Bruker AV400 spectrometer in $\mathrm{CDCl}_{3}$ or DMSO- $d_{6}$ solution with tetramethylsilane as the internal standard. HRMS data were obtained on an FTICR-MS instrument (Ionspec 7.0 T). The melting points were determined on an X-4 binocular microscope melting point apparatus without correction.

Biological assay. The anti-TMV, insecticidal and fungicidal activities of the synthesized compounds were tested using our previously reported methods ${ }^{38,39}$ and the methods can also be found in the "Supporting Information SI".

General synthesis. Ribavirin (Topscience Co., Ltd.), chlorothalonil (Bailing Agrochemical Co., Ltd.), carbendazim (Bailing Agrochemical Co., Ltd.) and other reagents were purchased from commercial sources and used as received. All anhydrous solvents were dried and purified according to standard techniques. The synthetic routes were given in Fig. 3 .

Echinopsine was prepared according to literature ${ }^{40}$. 


\begin{tabular}{|c|c|c|c|c|}
\hline \multirow[b]{2}{*}{ Compounds } & \multirow[b]{2}{*}{ Concentration $(\mathrm{mg} / \mathrm{L})$} & \multicolumn{3}{|c|}{ Relative inhibition rate (\%) } \\
\hline & & Inactivation effect & Curative effect & Protection effect \\
\hline 1 & 500 & $44.9 \pm 4.6$ & $39.8 \pm 2.6$ & $47.3 \pm 4.3$ \\
\hline 2 & 500 & $13.7 \pm 3.8$ & - & - \\
\hline 3 & 500 & $47.9 \pm 0.9$ & $43.7 \pm 3.1$ & $44.6 \pm 3.3$ \\
\hline 4 & 500 & $35.9 \pm 1.4$ & - & - \\
\hline 5 & 500 & $20.6 \pm 2.6$ & - & - \\
\hline 6 & 500 & \begin{tabular}{|l|}
$32.3 \pm 1.7$ \\
\end{tabular} & - & - \\
\hline 7 & 500 & $46.2 \pm 1.6$ & $45.0 \pm 3.7$ & $41.7 \pm 0.9$ \\
\hline 8 & 500 & $34.1 \pm 2.4$ & - & - \\
\hline 9 & 500 & $31.8 \pm 2.0$ & - & - \\
\hline 10 & 500 & $30.5 \pm 0.3$ & - & - \\
\hline 11 & 500 & $12.0 \pm 1.6$ & - & - \\
\hline 12 & 500 & $8.4 \pm 4.6$ & - & - \\
\hline 13 & 500 & $42.9 \pm 4.4$ & $31.1 \pm 2.8$ & $35.8 \pm 3.0$ \\
\hline 14 & 500 & \begin{tabular}{|l|}
$39.7 \pm 4.1$ \\
\end{tabular} & - & - \\
\hline 15 & 500 & $26.1 \pm 2.8$ & - & - \\
\hline 16 & 500 & \begin{tabular}{|l|}
$28.4 \pm 1.8$ \\
\end{tabular} & - & - \\
\hline 17 & 500 & \begin{tabular}{|l|}
$16.0 \pm 1.2$ \\
\end{tabular} & - & - \\
\hline 18 & 500 & $23.4 \pm 3.7$ & - & - \\
\hline 19 & 500 & \begin{tabular}{|l|}
$12.5 \pm 4.8$ \\
\end{tabular} & - & - \\
\hline 20 & 500 & $19.3 \pm 3.9$ & - & - \\
\hline 21 & 500 & $25.6 \pm 3.4$ & - & - \\
\hline 22 & 500 & $40.5 \pm 3.5$ & $34.7 \pm 4.0$ & $38.3 \pm 4.0$ \\
\hline 23 & 500 & $33.2 \pm 4.1$ & - & - \\
\hline 24 & 500 & $7.3 \pm 2.8$ & - & - \\
\hline 25 & 500 & $4.0 \pm 0.5$ & - & - \\
\hline 26 & 500 & \begin{tabular}{|l|}
$26.4 \pm 3.3$ \\
\end{tabular} & - & - \\
\hline 27 & 500 & $38.9 \pm 2.5$ & - & - \\
\hline \begin{tabular}{|l} 
Echinopsine \\
\end{tabular} & 500 & $49.5 \pm 4.4$ & $46.1 \pm 1.5$ & $42.6 \pm 2.3$ \\
\hline Ribavirin & 500 & $38.9 \pm 1.4$ & $39.2 \pm 1.8$ & $36.4 \pm 3.4$ \\
\hline
\end{tabular}

Table 1. In vivo antiviral activities of compounds 1-27 and echinopsine against TMV.

Synthesis of methyl 1-methyl-4-oxo-1,4-dihydroquinoline-3-carboxylate (B). To a round bottomed flask $(500 \mathrm{~mL})$ were added compound $\mathbf{A}(1.89 \mathrm{~g}, 10 \mathrm{mmol}), \mathrm{Cs}_{2} \mathrm{CO}_{3}(1.89 \mathrm{~g}, 10 \mathrm{mmol})$ and acetonitrile $(300 \mathrm{~mL})$. The reaction suspension was stirred for half an hour at room temperature and methyl iodide $(4.24 \mathrm{~g}$, $30 \mathrm{mmol}$ ) was added. The mixture was refluxed for $6 \mathrm{~h}$. Water $(200 \mathrm{~mL})$ was added and the reaction mixture was extracted with ethyl acetate for three times. The organic phases were combined, washed with brine, dried over anhydrous $\mathrm{Na}_{2} \mathrm{SO}_{4}$ and evaporated under reduced pressure. The residue was subjected to column chromatography eluted with dichloromethane / methanol (v/v, 50/1) to give compound $\mathbf{B}$ as a white solid (1.98 g, $91.2 \%$ yield); mp 189-190 ${ }^{\circ} \mathrm{C} .{ }^{1} \mathrm{H}$ NMR $\left(400 \mathrm{MHz}, \mathrm{CDCl}_{3}\right) \delta 8.53$ (d, $\left.J=8.0 \mathrm{~Hz}, 1 \mathrm{H}\right), 8.50(\mathrm{~s}, 1 \mathrm{H}), 7.71$ (dd, $J=8.0$, $8.0 \mathrm{~Hz}, 1 \mathrm{H}), 7.48-7.42(\mathrm{~m}, 2 \mathrm{H}), 3.93(\mathrm{~s}, 3 \mathrm{H}), 3.89(\mathrm{~s}, 3 \mathrm{H}) ;{ }^{13} \mathrm{C}$ NMR $\left(100 \mathrm{MHz}, \mathrm{CDCl}_{3}\right) \delta 174.5,166.7,150.1$, $139.9,132.9,129.1,128.0,125.5,115.7,110.7,52.3,41.5$; HRMS (ESI) calcd. for $\mathrm{C}_{12} \mathrm{H}_{12} \mathrm{NO}_{3}[\mathrm{M}+\mathrm{H}]^{+}$218.0812, found 218.0811 .

Synthesis of 1-methyl-4-oxo-1,4-dihydroquinoline-3-carbohydrazide (C). Compound B (4.34 g, $20 \mathrm{mmol}$ ) and hydrazine hydrate $(12.50 \mathrm{~g}, 200 \mathrm{mmol}, 80 \%)$ were dissolved in methanol $(300 \mathrm{~mL})$. The mixture was refluxed for $8 \mathrm{~h}$. The mixture was concentrated under reduced pressure until a large amount of solid precipitated. The mixture was filtered, washed with a small amount of methanol to give compound $\mathbf{C}$ as a white solid (4.20 g, 96.8\% yield); mp $273-275^{\circ} \mathrm{C} .{ }^{1} \mathrm{H}$ NMR $\left(400 \mathrm{MHz}, \mathrm{DMSO}-d_{6}\right) \delta 10.67(\mathrm{~s}, 1 \mathrm{H}), 8.86(\mathrm{~s}, 1 \mathrm{H}), 8.34(\mathrm{~d}$, $J=8.0 \mathrm{~Hz}, 1 \mathrm{H}), 7.88-7.81(\mathrm{~m}, 2 \mathrm{H}), 7.55(\mathrm{dd}, J=8.0,8.0 \mathrm{~Hz}, 1 \mathrm{H}), 4.58(\mathrm{~d}, J=4.4 \mathrm{~Hz}, 2 \mathrm{H}), 4.02(\mathrm{~s}, 3 \mathrm{H}) ;{ }^{13} \mathrm{C} \mathrm{NMR}$ $\left(100 \mathrm{MHz}, \mathrm{DMSO}-d_{6}\right) \delta 175.1,163.9,148.3,139.8,133.0,126.8,126.0,125.1,117.5,110.2,41.2$; HRMS (ESI) calcd. for $\mathrm{C}_{11} \mathrm{H}_{12} \mathrm{~N}_{3} \mathrm{O}_{2}[\mathrm{M}+\mathrm{H}]^{+} 218.0924$, found 218.0920.

General procedure for the preparation of compounds 1-27. To a round bottomed flask (100 mL) were added methanol $(50 \mathrm{~mL})$, compound $\mathbf{C}(3 \mathrm{mmol})$, one benzaldehyde from $\mathbf{D}_{1}-\mathbf{D}_{27}(3 \mathrm{mmol})$ and $p$-methylbenzene sulfonic acid $(0.6 \mathrm{mmol})$. The reaction suspension was refluxed for $8 \mathrm{~h}$. The reaction suspension was cooled to room temperature and partial methanol was evaporated under reduced pressure until a large amount of precipitation precipitated. The precipitate was filtered and washed several times with cool methanol to afford compounds 1-27. Data for compounds 1-27 can be found in the "Supporting Information SI". 
a<smiles></smiles>

Benquinox

(Fungicide)

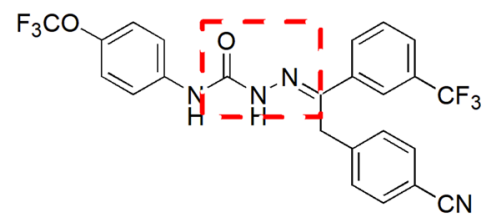

Metafiumizone

(Insecticide)

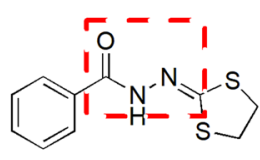

Saijunmao

(Bactericide)<smiles>O=C(NN=C(I)c1ncccc1C(=O)O)Nc1cc(F)cc(F)c1</smiles>

Diflufenzopyr

(Herbicide)

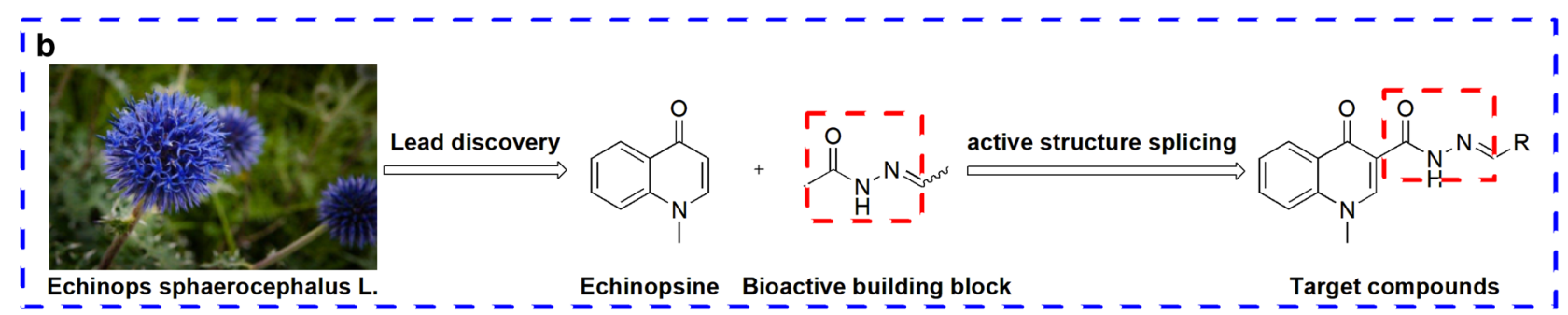

Figure 2. (a) Bioactive drugs containing acylhydrazone moieties; (b) design strategy for the target molecules.

\section{Results and discussion}

Synthesis. The preparation of compound B was carried out according to literature ${ }^{41}$ (Fig. 3). Acetonitrile was used as solvent instead of DMF and the reaction was accomplished in $91.2 \%$ yield. Then product $\mathbf{B}$ reacted with hydrazine hydrate under reflux to afford hydrazine $\mathbf{C}$, which can react subsequently with aldehyde $\mathbf{D}_{\mathbf{1}}-\mathbf{D}_{27}$ to give hydrazine 1-27 as products in 52.7-95.3\% yields. During the synthesis of acylhydrazone 1-27, only trans isomers were obtained, which may due to the fact that trans isomers are more stable than cis isomers thermodynamically. Compounds 1-27 can precipitate from methanol, which made the purification of acylhydrazone derivatives easy and suitable for large-scale production.

In vivo anti-TMV activity. The results of anti-TMV activities in vivo (inactivation, curative, and protection mode) of echinopsine and compounds 1-27 are listed in Table 1. In order to make the antiviral activity results more reliable, commercial plant virus inhibitor ribavirin was taken as control. In our previous work, the highly antiviral lead echinopsine was found, based on which a series of echinopsine derivatives containing acylhydrazone structure were synthesized in this work to study the influence of the variation of the functional groups on the antiviral activities of echinopsine. The antiviral results (Table 1) showed that some echinopsine acylhydrazone compounds exhibited moderate to good anti-TMV activity compared with ribavirin. Especially, the inactivation activity, curative activity, protection activity of compounds $\mathbf{1}(44.9 \pm 4.6,39.8 \pm 2.6$ and $47.3 \pm 4.3 \%, 500 \mathrm{mg} / \mathrm{L}), 3(47.9 \pm 0.9,43.7 \pm 3.1$, and $44.6 \pm 3.3 \%, 500 \mathrm{mg} / \mathrm{L}), 7(46.2 \pm 1.6,45.0 \pm 3.7$, and $41.7 \pm 0.9 \%, 500 \mathrm{mg} / \mathrm{L}$ ) were obviouly higher than that of commercialized anti-plant virus agent ribavirin $(38.9 \pm 1.4,39.2 \pm 1.8$, and $36.4 \pm 3.4 \%, 500 \mathrm{mg} / \mathrm{L})$.

For derivatives containing substituted phenyl (1-14), the electronic effect of the substituents on phenyl has an effect on the anti-TMV activities. The introduction of electron-withdrawing and electron-donating substituents led to the decrease of anti-TMV activities. For example, the structure-activity relationship shows the following: non-substituent $(\mathbf{1})>p$-hydroxyl (4) $>p$-phenoxy $(\mathbf{8})>p$-methylthio (9) $>p$-methoxy (5), non-substituent (1) $>p$-bromo substituent (13) $>p$-methylsulfonyl (10) $>p$-fluorosubstituent (11) $>p$-chloro substituent (12). However, there is no obvious linear relationship between anti-TMV activity and electron-donating and electronwithdrawing ability. For example, the structure-activity relationship shows the following: p-bromo substituent (13) $>p$-trifluoromethoxy substituent (14) $>p$-fluoro substituent (11) $>p$-chloro substituent (12), while the activity of compound 13 at $500 \mathrm{mg} / \mathrm{L}$ (inactivation activity, $42.9 \pm 4.4 \%$; curative activity, $31.1 \pm 2.8 \%$; protection activity, $35.8 \pm 3.0 \%$ ) is equivalent to that of ribavirin. The size of substituents also has an effect on the activities. For example, the activities of derivatives with a $p$-tert-butyl (3) and $p$-phenyl substituent (7) are higher than that with no substituents (1). Mono substitution or multi substitution on the benzene ring affected anti-TMV activity to a certain extent, for instance, compared with compounds 5 (inactivation, $20.6 \pm 2.6 \%, 500 \mathrm{mg} / \mathrm{L}$ ), the disubstituted compound 6 (inactivation, $32.3 \pm 1.7 \%, 500 \mathrm{mg} / \mathrm{L}$ ) exhibited higher activity.

The anti-TMV activities of compounds 15-26 containing heterocyclic ring reduced obviously compared with that of compounds containing benzene ring (1). Compound 22, showed the highest activities at $500 \mathrm{mg} / \mathrm{L}$ 
<smiles>O=C(O)c1c[nH]c2ccccc2c1=O</smiles>

A<smiles>COC(=O)c1cn(C)c2ccc([N+](C)(C)C)cc2c1=O</smiles>

B<smiles>Cn1cc(C(=O)NN)c(=O)c2cc(NN)ccc21</smiles>

C<smiles>[R]C=NNC(=O)c1cn(C)c2ccccc2c1=O</smiles>

1-27

$\mathrm{R}=$<smiles>Cc1ccccc1</smiles><smiles>Cc1ccc(Oc2ccccc2)cc1</smiles>

8<smiles>[Te]c1ccncc1</smiles>

15<smiles>CC(C)(C)c1c[nH]c2ccccc12</smiles>

22<smiles>Cc1ccc(C)cc1</smiles>

2<smiles>CSc1ccc(C(C)(C)C)cc1</smiles>

9<smiles>Cc1cccnc1</smiles>

16<smiles>Cc1cc2ccccc2o1</smiles>

23<smiles>CC(C)(C)c1ccccc1</smiles>

3<smiles>[Y20]c1ccc(S(C)(=O)=O)cc1</smiles>

10<smiles>C[Z20]1ccc2c(c1)OCCO2</smiles>

17<smiles>[Y]c1nc2ccccc2[nH]1</smiles>

24<smiles>Cc1ccc(O)cc1</smiles>

4<smiles>Cc1ccc(F)cc1</smiles>

11<smiles>Cc1ccco1</smiles>

18<smiles>CCn1c2ccccc2c2ccc(C)cc21</smiles>

25<smiles>COc1ccc(I)cc1</smiles>

5<smiles>[X]c1ccc(Cl)cc1</smiles>

12<smiles>CC(C)(C)c1ccc[nH]1</smiles>

19<smiles>CC(C)(C)c1cccc2cccnc12</smiles>

26<smiles>COc1cccc(OC)c1</smiles>

6<smiles>Cc1ccc(Br)cc1</smiles>

13<smiles>Cc1cccs1</smiles>

20<smiles>Nc1c2ccccc2cc2ccccc12</smiles>

27<smiles>Cc1ccc(-c2ccccc2)cc1</smiles>

7<smiles>CC(C)(C)c1ccc(OC(F)(F)F)cc1</smiles>

14<smiles>c1ccc2[nH]ccc2c1</smiles>

21

Figure 3. Synthesis of echinopsine acylhydrazone derivatives.

(inactivation activity, $40.5 \pm 3.5 \%$; curative activity, $34.7 \pm 4.0 \%$; protection activity, $38.3 \pm 4.0 \%$ ), which was equivalent to that of ribavirin. However, the activity was greatly reduced when the benzene ring was changed to an anthracene ring, that is, the activities of compound 27 (inactivation, $38.9 \pm 2.5 \%, 500 \mathrm{mg} / \mathrm{L}$ ) was lower than that of compound 1 (inactivation, $44.9 \pm 4.6 \%, 500 \mathrm{mg} / \mathrm{L}$ ).

Compound 3 showed the highest activities at $500 \mathrm{mg} / \mathrm{L}$ (inactivation activity, $47.9 \pm 0.9 \%$; curative activity, $43.7 \pm 3.1 \%$; protection activity, $44.6 \pm 3.3 \%$ ), which is significantly higher than that of ribavirin. Thus, this compound (3) can be selected as an anti-TMV candidate drug for further study.

Insecticidal activities. The insecticidal activities of the target compounds 1-27 and echinopsine against Lepidoptera pests, such as diamondback moth (Plutella xylostella), cotton bollworm (Helicoverpa armigera), corn borer (Ostrinia nubilalis), oriental armyworm (Mythimna separata) and fall armyworm (Spodoptera frugiperda (J. E. Smith)) are listed in Tables 2 and 3, echinopsine was taken as control.

The result showed that echinopsine and some derivatives showed broad spectrum insecticidal activities. Most of the compounds exhibited moderate to good larvicidal activities against $P$. xylostella. For derivatives containing substituted phenyl (1-14) and anthranyl (27), compounds 7, 14 and 27 exhibited $100 \pm 0 \%$ mortality at $600 \mathrm{mg} / \mathrm{L}$. In particular, compounds 7 and 27 still showed $67 \pm 6 \%$ and $53 \pm 6 \%$ mortality even at $0.1 \mathrm{mg} / \mathrm{L}$. Compounds 15, 21, 23, 25 and 26 containing heterocyclic ring also showed $100 \pm 0 \%$ mortality at $600 \mathrm{mg} / \mathrm{L}$, which was better than echinopsine $(90 \pm 0 \%$ at $600 \mathrm{mg} / \mathrm{L})$ (Table 2$)$.

At the same time, the insecticidal activities of compounds 15-26 containing heterocyclic ring against $M$. separata and $S$. frugiperda were higher than that of compounds 1-14 containing benzene ring. The compounds $5,9,14,21,24$ and 25 exhibited higher activities $(100 \pm 0 \%$ at $200 \mathrm{mg} / \mathrm{L})$ against $M$. separata than that of 


\begin{tabular}{|c|c|c|c|c|c|c|}
\hline \multirow[b]{2}{*}{ Compounds } & \multicolumn{6}{|c|}{ Larvicidal activity (mortality \%) at concn (mg/L) } \\
\hline & 600 & 200 & 100 & 10 & 1 & 0.1 \\
\hline 1 & $73 \pm 6$ & - & - & - & - & - \\
\hline 2 & 0 & - & - & - & - & - \\
\hline 3 & 0 & - & - & - & - & - \\
\hline 4 & $40 \pm 10$ & - & - & - & - & - \\
\hline 5 & $53 \pm 6$ & - & - & - & - & - \\
\hline 6 & $70 \pm 0$ & - & - & - & - & - \\
\hline 7 & $100 \pm 0$ & $100 \pm 0$ & $100 \pm 0$ & $100 \pm 0$ & $90 \pm 0$ & $67 \pm 6$ \\
\hline 8 & 0 & - & - & - & - & - \\
\hline 9 & $80 \pm 0$ & $57 \pm 6$ & - & - & - & - \\
\hline 10 & $77 \pm 0$ & - & - & - & - & - \\
\hline 11 & 0 & - & - & - & - & - \\
\hline 12 & $67 \pm 6$ & - & - & - & - & - \\
\hline 13 & $60 \pm 10$ & - & - & - & - & - \\
\hline 14 & $100 \pm 0$ & $90 \pm 0$ & $77 \pm 6$ & - & - & - \\
\hline 15 & $100 \pm 0$ & $100 \pm 0$ & $90 \pm 0$ & $60 \pm 0$ & - & - \\
\hline 16 & $67 \pm 6$ & - & - & - & - & - \\
\hline 17 & $40 \pm 10$ & - & - & - & - & - \\
\hline 18 & $70 \pm 0$ & - & - & - & - & - \\
\hline 19 & $83 \pm 6$ & $70 \pm 0$ & - & - & - & - \\
\hline 20 & 0 & - & - & - & - & - \\
\hline 21 & $100 \pm 0$ & $100 \pm 0$ & $100 \pm 0$ & $90 \pm 0$ & $57 \pm 6$ & - \\
\hline 22 & 0 & - & - & - & - & - \\
\hline 23 & $100 \pm 0$ & $90 \pm 0$ & $73 \pm 6$ & $47 \pm 6$ & - & - \\
\hline 24 & $83 \pm 6$ & $60 \pm 0$ & - & - & - & - \\
\hline 25 & $100 \pm 0$ & $93 \pm 6$ & $80 \pm 0$ & $60 \pm 0$ & - & - \\
\hline 26 & $100 \pm 0$ & $100 \pm 0$ & $80 \pm 0$ & $60 \pm 0$ & - & - \\
\hline 27 & $100 \pm 0$ & $100 \pm 0$ & $100 \pm 0$ & $100 \pm 0$ & $80 \pm 0$ & $53 \pm 6$ \\
\hline Echinopsine & $90 \pm 0$ & $70 \pm 0$ & - & - & - & - \\
\hline
\end{tabular}

Table 2. Insecticidal activity of compounds 1-27 and echinopsine against Diamond Back Moth (Plutella xylostella).

echinopsine $(70 \pm 0 \%$ at $200 \mathrm{mg} / \mathrm{L})$. Especially, compounds $\mathbf{9}$ and $\mathbf{2 4}$ showed $20 \pm 0 \%$ and $30 \pm 0 \%$ mortality at $50 \mathrm{mg} / \mathrm{L}$. In addition, the compounds 5, 21, 24, and 25 showed much higher activities ( $100 \pm 0 \%$ at $200 \mathrm{mg} / \mathrm{L})$ against $S$. frugiperda than that of echinopsine $(50 \pm 0 \%$ at $600 \mathrm{mg} / \mathrm{L})$. Especially, compounds 24 still showed $17 \pm 6 \%$ mortality at $50 \mathrm{mg} / \mathrm{L}$ (Table 3 ).

Fungicidal activity. The fungicidal results of compounds 1-27 and echinopsine are listed in Table 4. The commercial fungicide carbendazim and chlorothalonil were used as positive control. Overall, echinopsine and their derivatives exhibited broad-spectrum fungicidal activities against 14 kinds of phytopathogenic fungi. Most compounds showed relatively high fungicidal activities for Physalospora piricola and Sclerotinia sclerotiorum, among which the fungicidal activities of compounds 1-14 containing substituted phenyl were relatively higher than compounds 15-26 containing heterocyclic rings. Compound $\mathbf{1 3}$ and $\mathbf{1 4}$ showed more than 50\% inhibitory rate against five and six fungi respectively. Compound $\mathbf{2}$ showed the widest spectrum of fungicidal activity, with more than $60 \%$ inhibitory rate against eight fungi. Compound 7 exhibits $89.0 \pm 1.9 \%$ inhibitory rate against Rhizoctonia cerealis at $50 \mathrm{mg} / \mathrm{L}$, higher than carbendazim and chlorothalonil.

In summary, a series of novel echinopsine derivatives containing acylhydrazone moieties were designed, synthesized and their antiviral, insecticidal, and fungicidal activities were studied. The bioassays results showed that most compounds exhibited moderate to good anti-TMV activities in vivo, among which echinopsine (I) and its derivatives 1, 3, 7 showed higher anti-TMV activities than those of ribavirin, which can be used as lead structures for the development of anti-TMV drugs. Some compounds exhibited moderate to good insecticidal activity to $P$. xylostella, $M$. separata and $S$. frugiperda. In addition, most of these compounds exhibited good fungicidal activities against $P$. piricola and $S$. sclerotiorum. Further investigation on structural optimization and the mechanism of action are in progress in our laboratory. 


\begin{tabular}{|c|c|c|c|c|}
\hline \multirow[b]{2}{*}{ Compounds } & \multicolumn{4}{|c|}{$600 \mathrm{mg} / \mathrm{L}$, mortality $/ \%$} \\
\hline & H. armigera & O. nubilalis & M. separata & S. frugiperda \\
\hline 1 & $27 \pm 6$ & 0 & $50 \pm 0$ & $47 \pm 6$ \\
\hline 2 & $20 \pm 0$ & $10 \pm 0$ & $60 \pm 0$ & $30 \pm 0$ \\
\hline 3 & $10 \pm 0$ & 0 & $70 \pm 0$ & $70 \pm 0$ \\
\hline 4 & $10 \pm 0$ & $7 \pm 6$ & $40 \pm 0$ & $50 \pm 0$ \\
\hline 5 & 0 & 0 & $100 \pm 0 / 100 \pm 0^{\mathrm{a}} / 40 \pm 0^{\mathrm{b}}$ & $100 \pm 0 / 100 \pm 0^{\mathrm{a}} / 17 \pm 6^{\mathrm{b}}$ \\
\hline 6 & 0 & 0 & $10 \pm 0$ & $20 \pm 0$ \\
\hline 7 & $30 \pm 0$ & $20 \pm 0$ & $100 \pm 0 / 30 \pm 0^{\mathrm{a}}$ & $47 \pm 6$ \\
\hline 8 & $17 \pm 6$ & $7 \pm 6$ & $50 \pm 0$ & $47 \pm 6$ \\
\hline 9 & $37 \pm 6$ & $20 \pm 0$ & $100 \pm 0 / 100 \pm 0^{\mathrm{a}} / 60 \pm 0^{\mathrm{b}} / 20 \pm 0^{\mathrm{c}}$ & $60 \pm 0$ \\
\hline 10 & $10 \pm 0$ & 0 & $100 \pm 0 / 60 \pm 0^{\mathrm{a}}$ & $30 \pm 0$ \\
\hline 11 & $17 \pm 6$ & 0 & $40 \pm 0$ & $47 \pm 6$ \\
\hline 12 & $10 \pm 0$ & $13 \pm 6$ & $30 \pm 0$ & $30 \pm 0$ \\
\hline 13 & $23 \pm 6$ & $10 \pm 0$ & $60 \pm 0$ & $37 \pm 6$ \\
\hline 14 & $7 \pm 6$ & 0 & $100 \pm 0 / 100 \pm 0^{\mathrm{a}} / 40 \pm 0^{\mathrm{b}}$ & $40 \pm 0$ \\
\hline 15 & $10 \pm 0$ & 0 & $40 \pm 0$ & $10 \pm 0$ \\
\hline 16 & $30 \pm 0$ & $20 \pm 0$ & $100 \pm 0 / 60 \pm 0^{\mathrm{a}}$ & $30 \pm 0$ \\
\hline 17 & $30 \pm 0$ & $20 \pm 0$ & $70 \pm 0$ & $57 \pm 6$ \\
\hline 18 & $27 \pm 6$ & 0 & $60 \pm 0$ & $23 \pm 6$ \\
\hline 19 & $33 \pm 6$ & 0 & $80 \pm 0$ & $70 \pm 0$ \\
\hline 20 & $7 \pm 6$ & 0 & $50 \pm 0$ & $50 \pm 0$ \\
\hline 21 & 0 & 0 & $100 \pm 0 / 100 \pm 0^{\mathrm{a}} / 37 \pm 6^{\mathrm{b}}$ & $100 \pm 0 / 100 \pm 0^{\mathrm{a}} / 10 \pm 0^{\mathrm{b}}$ \\
\hline 22 & $10 \pm 0$ & 0 & $20 \pm 0$ & $20 \pm 0$ \\
\hline 23 & $47 \pm 6$ & $37 \pm 6$ & $100 \pm 0 / 50 \pm 0^{\mathrm{a}}$ & $67 \pm 6$ \\
\hline 24 & $23 \pm 6$ & $10 \pm 0$ & $100 \pm 0 / 100 \pm 0^{\mathrm{a}} / 100 \pm 0^{\mathrm{b}} / 30 \pm 0^{\mathrm{c}}$ & $100 \pm 0 / 100 \pm 0^{\mathrm{a}} / 100 \pm 0^{\mathrm{b}} / 17 \pm 6^{\mathrm{c}}$ \\
\hline 25 & $37 \pm 6$ & $7 \pm 6$ & $100 \pm 0 / 100 \pm 0^{\mathrm{a}} / 27 \pm 6^{\mathrm{b}}$ & $100 \pm 0 / 100 \pm 0^{\mathrm{a}} / 10 \pm 0^{\mathrm{b}}$ \\
\hline 26 & $17 \pm 6$ & 0 & $50 \pm 0$ & $10 \pm 0$ \\
\hline 27 & $27 \pm 6$ & $7 \pm 6$ & $30 \pm 0$ & $10 \pm 0$ \\
\hline Echinopsine & $30 \pm 0$ & $20 \pm 0$ & $100 \pm 0 / 70 \pm 0^{\mathrm{a}}$ & $50 \pm 0$ \\
\hline
\end{tabular}

Table 3. Insecticidal activity of compounds 1-27 and echinopsineagainst Cotton Bollworm (Helicoverpa armigera), Corn Borer (Ostrinia nubilalis), Oriental Armyworm (Mythimna separata), Fall Armyworm (Spodoptera Frugiperda (J. E. Smith)). ${ }^{\mathrm{a}}$ Mortality at $200 \mathrm{mg} / \mathrm{L}$, b ${ }^{\mathrm{b}}$ Mortality at $100 \mathrm{mg} / \mathrm{L}$, ${ }^{\mathrm{C}}$ Mortality at $50 \mathrm{mg} / \mathrm{L}$. 


\begin{tabular}{|c|c|c|c|c|c|c|c|c|c|c|c|c|c|c|}
\hline Compounds & $\mathrm{Fc}^{\mathrm{a}}$ & Ch & Pp & As & $\mathrm{Fg}$ & Fm & Ss & Pc & $\mathrm{Rc}$ & $\mathrm{Bm}$ & Wa & Rs & Bc & $\mathrm{Mg}$ \\
\hline 1 & $12.3 \pm 1.2$ & $6.7 \pm 0.9$ & $50.0 \pm 1.3$ & $38.9 \pm 0.6$ & $35.5 \pm 2.3$ & $11.6 \pm 1.7$ & $66.7 \pm 2.0$ & $19.4 \pm 1.2$ & $14.6 \pm 0.8$ & $9.6 \pm 1.3$ & $10.5 \pm 2.4$ & $27.8 \pm 1.9$ & $23.8 \pm 0.7$ & $11.1 \pm 1.4$ \\
\hline 2 & $38.6 \pm 1.8$ & $76.7 \pm 1.6$ & \begin{tabular}{|l|l}
$66.1 \pm 1.9$ \\
\end{tabular} & $61.1 \pm 0.9$ & $41.9 \pm 1.3$ & $65.1 \pm 0.8$ & $69.4 \pm 1.4$ & $22.6 \pm 0.9$ & \begin{tabular}{|l|l}
$64.6 \pm 1.9$ \\
\end{tabular} & $53.8 \pm 2.1$ & $52.6 \pm 2.8$ & $63.9 \pm 1.8$ & $38.1 \pm 2.0$ & $88.9 \pm 1.7$ \\
\hline 3 & $36.8 \pm 1.8$ & $6.7 \pm 0.8$ & $66.1 \pm 1.7$ & $38.9 \pm 2.7$ & $25.8 \pm 0.9$ & $25.6 \pm 1.9$ & $77.8 \pm 2.3$ & $16.1 \pm 0.7$ & $62.2 \pm 0.8$ & $7.7 \pm 1.3$ & $12.3 \pm 1.7$ & $5.6 \pm 0.8$ & $38.1 \pm 1.4$ & $5.6 \pm 1.1$ \\
\hline 4 & $19.3 \pm 0.8$ & $13.3 \pm 1.4$ & $35.5 \pm 0.9$ & $50.0 \pm 1.2$ & $41.9 \pm 0.6$ & $27.9 \pm 0.7$ & $75.0 \pm 1.8$ & $16.1 \pm 1.7$ & $13.4 \pm 0.8$ & $11.5 \pm 2.3$ & $17.5 \pm 1.5$ & $36.1 \pm 2.2$ & $23.8 \pm 1.9$ & $77.8 \pm 1.6$ \\
\hline 5 & $17.5 \pm 0.7$ & $10.0 \pm 1.7$ & $66.1 \pm 2.3$ & $16.7 \pm 1.4$ & $22.6 \pm 1.9$ & $34.9 \pm 2.4$ & $69.4 \pm 1.7$ & $19.4 \pm 0.9$ & $13.4 \pm 1.1$ & $5.8 \pm 1.2$ & $15.8 \pm 1.8$ & $27.8 \pm 0.8$ & $33.3 \pm 2.3$ & $22.2 \pm 0.7$ \\
\hline 6 & $45.6 \pm 1.8$ & $13.3 \pm 3.3$ & $82.3 \pm 2.4$ & $38.9 \pm 0.9$ & $25.8 \pm 1.2$ & $16.3 \pm 1.0$ & $80.6 \pm 1.9$ & $22.6 \pm 2.2$ & $25.6 \pm 0.7$ & $11.5 \pm 1.9$ & $19.3 \pm 0.9$ & $11.1 \pm 2.1$ & $33.3 \pm 0.9$ & $5.6 \pm 1.3$ \\
\hline 7 & $36.8 \pm 0.6$ & $10.0 \pm 0.7$ & $66.1 \pm 1.3$ & $38.9 \pm 0.8$ & $16.1 \pm 0.9$ & $25.6 \pm 1.4$ & $66.7 \pm 1.2$ & $9.7 \pm 1.1$ & $89.0 \pm 1.9$ & $7.7 \pm 0.7$ & $12.3 \pm 1.3$ & $36.1 \pm 0.8$ & $19.0 \pm 1.1$ & $44.4 \pm 1.7$ \\
\hline 8 & $36.8 \pm 0.6$ & $10.0 \pm 1.9$ & $74.2 \pm 2.2$ & $38.9 \pm 1.8$ & $22.6 \pm 1.4$ & $27.9 \pm 1.9$ & $69.4 \pm 0.7$ & $22.6 \pm 0.8$ & $53.7 \pm 1.2$ & $15.4 \pm 0.8$ & $17.5 \pm 1.4$ & $11.1 \pm 0.8$ & $57.1 \pm 2.3$ & $5.6 \pm 0.5$ \\
\hline 9 & $8.8 \pm 1.3$ & $33.3 \pm 1.4$ & $88.7 \pm 0.6$ & $38.9 \pm 1.2$ & $19.4 \pm 1.8$ & $39.5 \pm 0.9$ & $77.8 \pm 2.3$ & $16.1 \pm 2.4$ & $12.2 \pm 0.6$ & $11.5 \pm 1.1$ & $12.3 \pm 0.7$ & $5.6 \pm 1.4$ & $19.0 \pm 2.7$ & $11.1 \pm 0.8$ \\
\hline 10 & $45.6 \pm 1.9$ & $46.7 \pm 2.3$ & $82.3 \pm 1.5$ & $33.3 \pm 1.2$ & $25.8 \pm 2.8$ & $46.5 \pm 2.4$ & $77.8 \pm 1.3$ & $16.1 \pm 1.7$ & $56.1 \pm 1.3$ & $15.4 \pm 1.8$ & $21.1 \pm 1.1$ & $13.9 \pm 0.6$ & $23.8 \pm 0.9$ & $22.2 \pm 1.7$ \\
\hline 11 & $15.8 \pm 0.6$ & $6.7 \pm 1.1$ & $50.0 \pm 2.4$ & $44.4 \pm 3.1$ & $19.4 \pm 0.7$ & $34.9 \pm 1.2$ & $61.1 \pm 0.9$ & $6.5 \pm 0.8$ & $11.0 \pm 0.3$ & $7.7 \pm 0.6$ & $15.8 \pm 1.6$ & $11.1 \pm 0.6$ & $23.8 \pm 1.4$ & $11.1 \pm 0.7$ \\
\hline 12 & $22.8 \pm 1.8$ & $53.3 \pm 2.2$ & $51.6 \pm 3.4$ & $16.7 \pm 2.3$ & $25.8 \pm 0.8$ & $55.8 \pm 1.6$ & $63.9 \pm 2.9$ & $6.5 \pm 1.0$ & $35.4 \pm 3.1$ & $34.6 \pm 1.7$ & $26.3 \pm 1.8$ & $5.6 \pm 0.7$ & $23.8 \pm 1.5$ & $11.1 \pm 1.1$ \\
\hline 13 & $36.8 \pm 2.0$ & $33.3 \pm 1.1$ & $87.1 \pm 2.3$ & $50.0 \pm 2.8$ & $29.0 \pm 2.2$ & $37.2 \pm 1.4$ & $61.1 \pm 0.8$ & $9.7 \pm 0.9$ & $74.4 \pm 1.4$ & $48.1 \pm 2.8$ & $15.8 \pm 0.7$ & $38.9 \pm 1.8$ & $23.8 \pm 2.3$ & $66.7 \pm 1.9$ \\
\hline \begin{tabular}{|l|}
14 \\
\end{tabular} & $19.3 \pm 3.3$ & 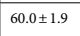 & \begin{tabular}{|l}
$7.2 \pm 2.2$ \\
\end{tabular} & $27.8 \pm 1.2$ & $6.5 \pm 1.4$ & \begin{tabular}{|l}
$65.1 \pm 0.8$ \\
\end{tabular} & $55.6 \pm 3.3$ & $6.5 \pm 1.2$ & \begin{tabular}{|l|l}
$50.0 \pm 0.9$ \\
\end{tabular} & $50.0 \pm 2.0$ & $43.9 \pm 1.9$ & $8.3 \pm 0.9$ & $9.5 \pm 1.1$ & $5.6 \pm 0.6$ \\
\hline 15 & $10.5 \pm 1.2$ & $43.3 \pm 2.0$ & $51.6 \pm 0.7$ & $38.9 \pm 0.8$ & $29.0 \pm 1.5$ & $18.6 \pm 1.7$ & $75.0 \pm 0.9$ & $25.8 \pm 2.1$ & \begin{tabular}{|l}
$13.4 \pm 1.4$ \\
\end{tabular} & $15.4 \pm 0.7$ & $19.3 \pm 3.3$ & $19.4 \pm 1.2$ & $23.8 \pm 0.6$ & $11.1 \pm 0.5$ \\
\hline 16 & $15.8 \pm 0.9$ & $10.0 \pm 3.2$ & $33.9 \pm 1.2$ & $16.7 \pm 1.1$ & $3.2 \pm 0.8$ & $25.6 \pm 1.3$ & $66.7 \pm 2.1$ & $16.1 \pm 0.7$ & \begin{tabular}{|l|l}
$37.8 \pm 3.1$ \\
\end{tabular} & $11.5 \pm 0.3$ & $17.5 \pm 0.8$ & $11.1 \pm 1.9$ & $23.8 \pm 1.4$ & $5.6 \pm 0.6$ \\
\hline 17 & $10.5 \pm 0.8$ & $3.3 \pm 0.6$ & $74.2 \pm 1.9$ & $38.9 \pm 2.3$ & $29.0 \pm 0.3$ & $20.9 \pm 1.2$ & $72.2 \pm 1.7$ & $6.5 \pm 1.0$ & \begin{tabular}{|l|l|}
$17.1 \pm 0.9$ \\
\end{tabular} & $1.9 \pm 1.1$ & $14.0 \pm 0.7$ & $25.0 \pm 0.9$ & $14.3 \pm 0.6$ & $66.7 \pm 1.4$ \\
\hline 18 & $10.5 \pm 0.4$ & $26.7 \pm 2.1$ & $71.0 \pm 2.9$ & $27.8 \pm 1.2$ & $22.6 \pm 2.4$ & $39.5 \pm 1.7$ & $75.0 \pm 3.4$ & $22.6 \pm 0.8$ & $39.0 \pm 2.2$ & $21.2 \pm 1.8$ & $28.1 \pm 1.7$ & $30.6 \pm 2.4$ & $28.6 \pm 2.3$ & $22.2 \pm 1.6$ \\
\hline 19 & $10.5 \pm 1.6$ & $23.3 \pm 2.0$ & $71.0 \pm 1.8$ & $33.3 \pm 1.3$ & $32.3 \pm 0.9$ & $20.9 \pm 2.2$ & $77.8 \pm 1.9$ & $16.1 \pm 2.0$ & $19.5 \pm 1.6$ & $11.5 \pm 1.2$ & $10.5 \pm 0.5$ & $50.0 \pm 1.5$ & $33.3 \pm 1.4$ & $55.6 \pm 2.8$ \\
\hline 20 & $15.8 \pm 0.7$ & $13.3 \pm 0.9$ & $41.9 \pm 1.2$ & $38.9 \pm 3.3$ & $29.0 \pm 0.9$ & $0.0 \pm 0.0$ & $55.6 \pm 1.4$ & $29.0 \pm 1.2$ & \begin{tabular}{|l}
$13.4 \pm 1.9$ \\
\end{tabular} & $11.5 \pm 0.8$ & $15.8 \pm 0.9$ & $13.9 \pm 1.3$ & $9.5 \pm 1.1$ & $11.1 \pm 0.6$ \\
\hline 21 & $17.5 \pm 1.6$ & $3.3 \pm 0.9$ & $40.3 \pm 2.2$ & $33.3 \pm 1.3$ & $22.6 \pm 0.6$ & $23.3 \pm 0.7$ & $80.6 \pm 2.4$ & $12.9 \pm 1.3$ & $14.6 \pm 0.8$ & $3.8 \pm 1.1$ & $12.3 \pm 0.8$ & $27.8 \pm 2.2$ & $19.0 \pm 1.4$ & $55.6 \pm 1.8$ \\
\hline 22 & $22.8 \pm 1.7$ & $3.3 \pm 0.5$ & $50.0 \pm 1.2$ & $38.9 \pm 1.3$ & $16.1 \pm 0.8$ & $20.9 \pm 1.2$ & $75.0 \pm 1.4$ & $16.1 \pm 2.3$ & $63.4 \pm 2.0$ & $9.6 \pm 0.5$ & $10.5 \pm 0.7$ & $13.9 \pm 0.9$ & $38.1 \pm 1.6$ & $11.1 \pm 0.5$ \\
\hline 23 & $19.3 \pm 0.7$ & $53.3 \pm 2.2$ & $45.2 \pm 1.5$ & $22.2 \pm 1.8$ & $16.1 \pm 1.2$ & \begin{tabular}{|l|l|}
$48.8 \pm 2.1$ \\
\end{tabular} & $55.6 \pm 1.9$ & $22.6 \pm 1.3$ & $56.1 \pm 3.2$ & $17.3 \pm 0.7$ & $26.3 \pm 1.7$ & $19.4 \pm 0.7$ & $23.8 \pm 2.3$ & $5.6 \pm 0.7$ \\
\hline 24 & $12.3 \pm 0.5$ & $6.7 \pm 0.7$ & $35.5 \pm 1.2$ & $38.9 \pm 2.3$ & $32.3 \pm 1.6$ & $16.3 \pm 2.1$ & $66.7 \pm 1.7$ & $16.1 \pm 1.9$ & $26.8 \pm 0.9$ & $7.7 \pm 0.6$ & $10.5 \pm 0.9$ & $22.2 \pm 1.4$ & $23.8 \pm 0.9$ & $5.6 \pm 0.6$ \\
\hline 25 & $10.5 \pm 2.2$ & $6.7 \pm 0.9$ & \begin{tabular}{|l|l|}
$50.0 \pm 1.4$ \\
\end{tabular} & $38.9 \pm 2.3$ & $25.8 \pm 1.3$ & $34.9 \pm 0.8$ & $66.7 \pm 0.9$ & $9.7 \pm 1.2$ & $17.1 \pm 1.8$ & $11.5 \pm 0.6$ & $15.8 \pm 2.4$ & $5.6 \pm 0.6$ & $23.8 \pm 2.3$ & $11.1 \pm 0.8$ \\
\hline 26 & $10.5 \pm 0.5$ & $10.0 \pm 2.3$ & $87.1 \pm 2.4$ & $33.3 \pm 1.4$ & $25.8 \pm 1.9$ & $25.6 \pm 2.2$ & $63.9 \pm 3.4$ & $6.5 \pm 0.6$ & $11.0 \pm 0.8$ & $9.6 \pm 1.9$ & $12.3 \pm 1.4$ & $5.6 \pm 0.9$ & $23.8 \pm 1.6$ & $11.1 \pm 0.7$ \\
\hline 27 & $10.5 \pm 2.1$ & $3.3 \pm 0.6$ & $74.2 \pm 1.6$ & $33.3 \pm 2.3$ & $38.7 \pm 0.9$ & $16.3 \pm 1.1$ & $13.9 \pm 1.6$ & $9.7 \pm 1.4$ & $18.3 \pm 1.8$ & $9.6 \pm 0.7$ & $17.5 \pm 2.2$ & $5.6 \pm 0.8$ & $9.5 \pm 0.6$ & $11.1 \pm 1.0$ \\
\hline Echinopsine & $10.5 \pm 1.4$ & $20.0 \pm 1.9$ & $58.1 \pm 2.2$ & $16.7 \pm 2.4$ & $19.4 \pm 2.2$ & $37.2 \pm 0.9$ & $69.4 \pm 1.7$ & $16.1 \pm 0.8$ & $18.3 \pm 2.2$ & $15.4 \pm 0.8$ & $14.0 \pm 1.3$ & $22.2 \pm 1.7$ & $28.6 \pm 0.6$ & $11.1 \pm 1.2$ \\
\hline carbendazim & $<50.0$ & $<50.0$ & $<50.0$ & $<50.0$ & $100.0 \pm 0.0$ & $100.0 \pm 0.0$ & $100.0 \pm 0.0$ & $100.0 \pm 0.0$ & $<50.0$ & $100.0 \pm 0.0$ & $<50.0$ & $100.0 \pm 0.0$ & $<50.0$ & $100.0 \pm 0.0$ \\
\hline chlorothalonil & $100.0 \pm 0.0$ & $73.3 \pm 1.2$ & $100.0 \pm 0.0$ & $100.0 \pm 0.0$ & $100.0 \pm 0.0$ & $<50.0$ & $86.4 \pm 1.3$ & $91.3 \pm 0.9$ & $73.3 \pm 0.9$ & $<50.0$ & $100.0 \pm 0.0$ & $100.0 \pm 0.0$ & $100.0 \pm 0.0$ & $91.3 \pm 0.8$ \\
\hline
\end{tabular}

Table 4. Fungicidal activity of compounds 1-27 and echinopsine against fourteen kinds of phytopathogens (50 mg/L, inhibition rate/\%). ${ }^{\mathrm{a}} \mathrm{Fc}$, Fusarium oxysporium $f$. sp. cucumeris; Ch, Cercospora arachidicola Hori; Pp, Physalospora piricola; As, Alternaria solani; Fg, Fusarium graminearum; Fm, Fusarium moniliforme; Ss, Sclerotinia sclerotiorum; Pc, Phytophthora capsici; Rc, Rhizoctonia cerealis; Bm,Bipolaris maydis; Wa, watermelon anthracnose; Rs, Rhizoctonia solani; Bc, Botrytis cinereaand; $M g$, magnaporthe grisea.

Received: 21 October 2021; Accepted: 4 February 2022

Published online: 21 February 2022

\section{References}

1. Vega, A., Gutiérrez, R. A., Peña-Neira, A., Cramer, G. R. \& Arce-Johnson, P. Compatible GLRaV-3 viral infections affect berry ripening decreasing sugar accumulation and anthocyanin biosynthesis in Vitis vinifera. Plant Mol. Biol. 77, 261-274 (2011).

2. Jones, R. A. C. et al. Principles of predicting plant virus disease epidemics. Annu. Rev. Phytopathol. 48, 179-203 (2010).

3. Scholthof, K. B. G. et al. Top 10 plant viruses in molecular plant pathology. Mol. Plant. Pathol. 12, 938-954 (2011).

4. Scholthof, K. B. G. Tobacco mosaic virus: A model system for plant biology. Annu. Rev. Phytopathol. 42, 13-34 (2004).

5. Chen, M. et al. Antibacterial and antiviral activities and action mechanism of flavonoid derivatives with a benzimidazole moiety. J. Saudi Chem. Soc. 25, 101194 (2021).

6. Bos, L. 100 years of virology: From vitalism via molecular biology to genetic engineering. Trends Microbiol. 8, 82-87 (2000).

7. Huang, Y. Q. et al. Design, synthesis, and biological activity of $\beta$-carboline analogues containing hydantoin, thiohydantoin, and urea moieties. J. Agric. Food Chem. 66, 8253-8261 (2018).

8. Gan, X. H. et al. Design, synthesis, antiviral activity and 3D-QSAR study of novel 1,4-pentadien-3-one derivatives containing the 1,3,4-oxadiazole moiety. Pest Manag. Sci. 72, 534-543 (2015).

9. Qian, X. H., Lee, P. W. \& Cao, S. China: Forward to the green pesticides via a basic research program. J. Agric. Food Chem. 58, 2613-2623 (2010).

10. Seiber, J. N. Sustainability and agricultural and food chemistry. J. Agric. Food Chem. 59, 1-21 (2011).

11. Zhang, J. et al. Purine nucleoside derivatives containing a sulfa ethylamine moiety: Design, synthesis, antiviral activity, and mechanism. J. Agric. Food Chem. 69, 5575-5582 (2021).

12. An, T. Y. et al. Alkaloids from Cyanachum komarovii with inhibitory activity against the tobacco mosaic virus. Phytochemistry $\mathbf{5 8}$, 1267-1269 (2001).

13. Li, L. et al. Synthesis and anti-tobacco mosaic virus/fungicidal/insecticidal/antitumor bioactivities of natural product hemigossypol and its derivatives. J. Agric. Food Chem. 69, 1224-1233 (2021).

14. Tian, Z. Y. et al. Toad alkaloid for pesticide discovery: Dehydrobufotenine derivatives as novel agents against plant virus and fungi. J. Agric. Food Chem. 69, 9754-9763 (2021).

15. Wang, T. N. et al. Pityriacitrin marine alkaloids as novel antiviral and anti-phytopathogenic-fungus agents. Pest. Manag. Sci. 77, 4691-4700 (2021).

16. Zhang, M. J. et al. Marine natural product for pesticide candidate: Pulmonarin alkaloids as novel antiviral and anti-phytopathogenic-fungus agents. J. Agric. Food Chem. 68, 11350-11357 (2020).

17. Wang, T. N. et al. Structural simplification of marine natural products: Discovery of hamacanthin derivatives containing indole and piperazinone as novel antiviral and anti-phytopathogenic-fungus agents. J. Agric. Food Chem. 69, 10093-10103 (2021). 
18. Yang, S. et al. Discovery of cysteine and its derivatives as novel antiviral and antifungal agents. Molecules 26, 383 (2021).

19. Zou, J. B. et al. Quinolizidine alkaloids with antiviral and insecticidal activities from the seeds of Sophora tonkinensis gagnep. J. Agric. Food Chem. 68, 15015-15026 (2020).

20. Zhang, X. P. et al. Identification of carbazole alkaloid derivatives with acylhydrazone as novel anti-TMV agents with the guidance of a digital fluorescence visual screening. J. Agric. Food Chem. 69, 7458-7466 (2021).

21. Kumari, A., Suresh, M. \& Singh, R. B. Total synthesis of the proposed structure of anti-TMV active tabasesquiterpene A. Tetrahedron 92, 132282 (2021).

22. Li, Y. T. et al. Identification of anti-TMV active flavonoid glycosides and their mode of action on virus particles from clematis lasiandra maxim. Pest. Manag. Sci. 77, 5268-5277 (2021).

23. Sivaraman, A. et al. Synthesis and cytotoxicity studies of bioactive benzofurans from Lavandula agustifolia and modified synthesis of ailanthoidol, homoegonol, and egonol. J. Nat. Prod. 83, 3354-3362 (2020).

24. Lv, X. et al. The Enhancement of antiviral activity of chloroinconazide by aglinate-based nanogel and its plant growth promotion effect. J. Agric. Food Chem. 69, 4992-5002 (2021).

25. Liu, H. et al. Transcriptomic and functional analyses indicate novel anti-viral mode of actions on tobacco mosaic virus of a microbial natural product $\xi$-poly-L-lysine. J. Agric. Food Chem. 69, 2076-2086 (2021).

26. Huang, X. B. et al. High value-added use of citrus industrial wastes in agriculture: Semisynthesis and anti-tobacco mosaic virus/ insecticidal activities of ester derivatives of limonin modified in the bring. J. Agric. Food Chem. 68, 12241-12251 (2020).

27. Peng, F. et al. Antibacterial and antiviral activities of 1,3,4-oxadiazole thioether $4 \mathrm{H}$-chromen-4-one derivatives. J. Agric. Food Chem. 69, 11085-11094 (2021).

28. Kiyekbayeva, L. et al. Phytochemical constituents and antioxidant activity of Echinops albicaulis. Nat. Prod. Res. 32, 1203-1207 (2018).

29. Shang, X. F. et al. Biologically active quinoline and quinazoline alkaloids part I. Med. Res. Rev. 38, 775-828 (2018).

30. Zhao, P. L., Li, J. \& Yang, G. F. Synthesis and insecticidal activity of chromanone and chromone analogues of diacylhydrazines. Bioorg. Med. Chem. 15, 1888-1895 (2007).

31. Chen, Q., Liu, Z. M., Chen, C. N., Jiang, L. L. \& Yang, G. F. Synthesis and fungicidal activities of new 1,2,4-triazolo[1,5-a]-pyrimidines. Chem. Biodivers. 6, 1254-1265 (2009).

32. Jin, Y. X., Zhong, A. G., Zhang, Y. J. \& Pan, F. Y. Synthesis, crystal structure, spectroscopic properties, antibacterial activity and theoretical studies of a novel difunctional acylhydrazone. J. Mol. Struct. 1002, 45-50 (2011).

33. Liu, X. H., Liu, H. J., Tan, C. X. \& Weng, J. Q. Application of acylhydrazonederivatives as fungicide. CN 101874496A, 2010-06-30.

34. Hamadache, M. et al. A quantitative structure activity relationship for acute oral toxicity of pesticides on rats: Validation, domain of application and prediction. J. Hazard. Mater. 303, 28-40 (2016).

35. Keshavarz, M. H. \& Pouretedal, H. R. Simple and reliable prediction of toxicological activities of benzoic acid derivatives without using any experimental data or computer codes. Med. Chem. Res. 22, 1238-1257 (2013).

36. Jose, L. et al. Metaflumizone, a new broad-spectrum insecticide for crop protection. In Congress Proceedings 2007 of the XVI International Plant Protection Congress (British Crop Protection Council, 2007).

37. Lym, R. G. \& Christianson, K. M. Diflufenzopyr increases perennial weed control with auxin herbicides. Proc. West. Soc. Weed Sci. 51, 59-62 (1998).

38. Wang, K. L. et al. Synthesis and antiviral activities of phenanthroindolizidine alkaloids and their derivatives. J. Agric. Food Chem. 58, 2703-2709 (2010).

39. Zhao, H. P. et al. Design, synthesis, and biological activities of arylmethylamine substituted chlorotriazine and methylthiotriazine compounds. J. Agric. Food Chem. 59, 11711-11717 (2011).

40. Guo, Y. F. \& Harutyunyan, S. R. Highly enantioselective catalytic addition of grignard reagents to N-heterocyclic acceptors. Angew. Chem. Int. Ed. 58, 12950-12954 (2019).

41. Mori, S. et al. Structural development of a type-1 ryanodine receptor (RyR1) $\mathrm{Ca}^{2+}$-release channel inhibitor guided by endoplasmic reticulum $\mathrm{Ca}^{2+}$ assay. Eur. J. Med. Chem. 179, 837-848 (2019).

\section{Author contributions}

P.C., M.C. and Y.M. completed the synthesis of compounds. Y.Y. summarized the structure-activity relationship of echinopsine derivatives. Y.Y., Y.L. and Q.W. wrote, edited and reviewed the paper. Q.W. supervised the whole research work. All authors reviewed the manuscript.

\section{Funding}

The authors are grateful to the National Natural Science Foundation of China (21702144 and 22001190) and Shanxi Applied Basic Research Program (201801D221123), Shanxi Province Scientific and Technological Innovation Project of Colleges (2019L0123).

\section{Competing interests}

The authors declare no competing interests.

\section{Additional information}

Supplementary Information The online version contains supplementary material available at https://doi.org/ 10.1038/s41598-022-06775-7.

Correspondence and requests for materials should be addressed to Y.Y. or Q.W.

Reprints and permissions information is available at www.nature.com/reprints.

Publisher's note Springer Nature remains neutral with regard to jurisdictional claims in published maps and institutional affiliations. 
(c) (i) Open Access This article is licensed under a Creative Commons Attribution 4.0 International cc) License, which permits use, sharing, adaptation, distribution and reproduction in any medium or format, as long as you give appropriate credit to the original author(s) and the source, provide a link to the Creative Commons licence, and indicate if changes were made. The images or other third party material in this article are included in the article's Creative Commons licence, unless indicated otherwise in a credit line to the material. If material is not included in the article's Creative Commons licence and your intended use is not permitted by statutory regulation or exceeds the permitted use, you will need to obtain permission directly from the copyright holder. To view a copy of this licence, visit http://creativecommons.org/licenses/by/4.0/.

(C) The Author(s) 2022 